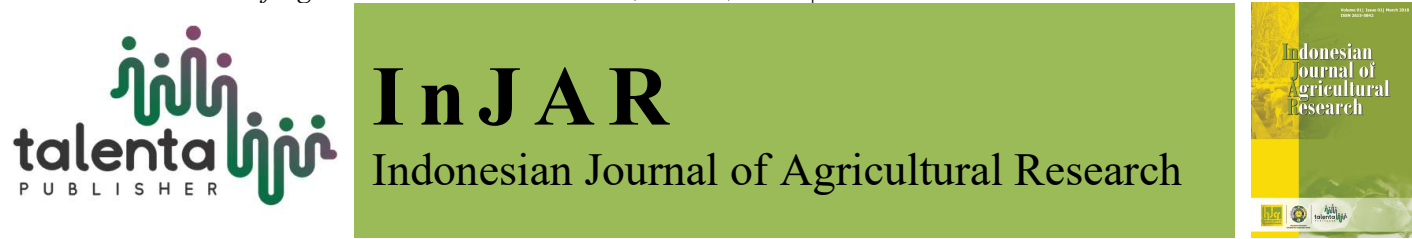

\title{
The Role of Mungbean (Phaseolus radiatus) as a Fat Replacer on the Physicochemical Properties of Ice Cream
}

\author{
Pulung Nugroho $^{1 *}$, Laksmi Hartayanie ${ }^{2}$, and Kartika Puspa Dwiana ${ }^{2}$ \\ ${ }^{1}$ Faculty of Medicine and Health Sciences, Food Technology Study Program, Satya Wacana Christian \\ University, Salatiga, Indonesia \\ ${ }^{2}$ Faculty of Agriculture, Food Technology Study Program, Soegijapranata Katholik University, \\ Semarang, Indonesia
}

\begin{abstract}
Fat replacer can be an alternative in the processing of making ice cream. The use of fat replacers can replace the role of fat as forming texture, flavor, and aroma without reducing the quality of the ice cream. In this research, green beans we used as a fat replacer as a substitution to whipped cream. Mung beans are a high source of protein and carbohydrates. The purpose of this study was to determine the physicochemical characteristics of ice cream with the addition of mung bean flour and determine the optimal ratio of whipped cream optimal and mung bean as a fat replacer. Based on the results of research that has been done ice cream with a ratio of green bean flour: whipped cream (50: 50) has the best quality with a fat content of $7.74 \%$, overrun $78.13 \%$, hardness $17.46 \mathrm{kgf}$, viscosity $1170 \mathrm{cP} . \mathrm{S}$, melting time is 49.17 minutes. It was concluded that the best ice cream was produced from addition of $25 \%$ and $50 \%$ green bean flour.
\end{abstract}

Keywords: fat replacer, green beans, ice cream, whipped cream

Received 20 November 2019 | Revised 26 November 2019 | Accepted 3 January 2020

\section{Introduction}

Nowadays the trend of consumption of food products has been directed more to consuming healthy food, as the communities are more aware of their health and nutrition intake. The development of extensive information, makes it easier for people to access knowledge related to the food products, such as ice cream. In general, ice cream is a product that is processed using raw materials derived from fats such as milk and coconut milk. Ice cream is composed of $60 \%$ fat from total dry matter [1]. The ice cream component consists of milk, whipped cream, sugar, emulsifier, and stabilizer. Ice cream is composed of 55-64\% moisture and $36-38 \%$ total solid, with $10-16 \%$ fat (145 calories per 100 grams) [2].

\footnotetext{
*Corresponding author at: Faculty of Medicine and Health Sciences, Food Technology Study Program, Satya Wacana Christian University, Jl. Diponegoro 52-60, Salatiga, 50711, Indonesia

E-mail address: pulung.nugroho@uksw.edu
}

Copyright $(C$ Indonesian Journal of Agricultural Research 2019 Published by Talenta Publisher p-ISSN: 2622-7681 | e-ISSN: 2615-5842 | DOI 10.32734/injar.v2i3.2859

Journal Homepage: https://talenta.usu.ac.id/InJAR 
Ice cream is a product that has the potential for high-fat content, while consumers prefer to consume low-fat food. Fat in ice cream functions as a form of mouth feel, aroma, flavor, and texture of ice cream. The decreased of fat content in ice cream will have a negative impact, especially on the quality of ice cream. In contrast, the consumers demand a low fat ice cream, that is not changed in its acceptance and taste [3] [4]. Therefore, fat replacer can be a solution to reduce fat content in ice cream. Fat replacer is a material that is able to act like fat, especially to form textures. In addition, the fat replacer should be safe and physiologically able to provide the same quality product. Moreover, the replacer should be able to reduce calorie value maintain the desired functional and sensory properties [5]. In terms of the nutritional value, the fat substitute or fat replacer can act as macronutrient substances such as fat [6]. Fat replacer is divided into three types, namely fat replacer carbohydrate-based, fat replacer protein-based, and fat replacer fat-based.

Mung beans or Phaseolus radiatus L. are from the family Leguminoseae or legumes. Mung beans comprise of 22 grams of protein, 57 grams of carbohydrates, and 1.5 grams of fat per 100 grams. In addition, green beans contain $28.8 \%$ amylose and $71.2 \%$ amylopectin [7]. Based on this, green beans have the potential as a fat replacer related to its functional value to form an ice cream texture. In other words, the function of green beans in this study is to replace the role of whipped cream as a source of fat to form textures to reduce ice cream fat. Furthermore, the substitution of green beans serves to increase the functionality of ice cream. The other advantages are the mung beans also contain essential amino components acids such as isoleucine, leucine, lysine, methionine, phenylalanine, threonine, valine, and non-essential amino acids such as alanine, arginine, aspartic acid, glutamic acid, glycine, tryptophan, and tyrosine [7].

\section{Materials and Methods}

The equipment used in this study was a mixer, freezer, stove, thermometer, measuring cup, funnel, viscometer, ice cream maker brand Simac II series Gelataio 810, stopwatch, Soxhlet, extruder, oven, Kjehdahl flask. The ingredients used in this study were green beans, whipped cream, sugar, salt, milk, $\mathrm{K} 2 \mathrm{SO} 4, \mathrm{HCl}$, aquades, $\mathrm{NaOH}$, alcohol.

\subsection{Mung Bean Flour Making}

The process of mung bean flour is done by extruding mung beans using an extruder to obtain flour. The result of the extrusion is then smoothed by blending. Then proceed with the sifting process with a size of 625 mesh. 


\subsection{Ice Cream Making Procedure}

Mix all ingredients such as mung bean flour, sugar, salt, warm water and pasteurized cow's milk for 25 minutes. Then prepare the second ingredient mixture whipped cream and cold water that has been mixed. Treatment of mung bean flour: whipped cream:

Table 1. Comparison of mung bean flour and whipped cream

\begin{tabular}{ccc}
\hline Treatment of & Mung bean flour (\%) & Whipped cream (\%) \\
\hline A & 0 & 100 \\
B & 25 & 75 \\
C & 50 & 50 \\
D & 75 & 25 \\
\hline
\end{tabular}

Description:

A: $0 \%$ mung bean flour: $100 \%$ whipped cream

B: $25 \%$ mung bean flour: $75 \%$ whipped cream

C: $50 \%$ mung bean flour: $50 \%$ whipped cream

D: $75 \% \%$ mung bean flour: $25 \%$ whipped cream

All the mixture were then mixed then put into the ice cream maker with a mixing process for 30 minutes.

\subsection{Data Analysis}

The analysis includes physical, chemical and sensory observations. Physical properties include overrun, viscosity, and melting rate. The chemical analysis comprises of proximate analysis moisture, fat, protein, and starch content.

\subsubsection{Overrun}

Overrun is measured by measuring the volume of the initial mixture and the volume of the final mixture. The volume of the initial mixture is obtained from the mixture of starting ingredients which have been mixed. While the final dough volume is obtained after the ice cream undergoes a mixing process in the ice cream maker. The final dough volume can be obtained after the ice cream is formed. Then \% overrun is calculated using the formula: [8]

$$
\% \text { overrun }=\frac{(\text { vol.of ice cream-vo .of Mix.used })}{\text { vol.of } \text { Mix.used }} \times 100 \%
$$

\subsubsection{Viscosity}

Perform viscosity measurements by means of ice cream that has been allowed to stand overnight then do viscosity testing. The test is carried out by means of the ice cream left to stand at room temperature until a temperature of $3-5 \mathrm{oC}[8]$.

\subsubsection{Hardness}

The measurement of ice cream hardness is done using a texture analyzer. The type of probe in the texture analyzer used to test samples is a ball probe, a probe that has a ball-like shape with a 
capacity of $500 \mathrm{~N}$ ( $50.9 \mathrm{kgf}, 112.5 \mathrm{lbf})$. The test speed used is $5 \mathrm{~mm} / \mathrm{s}$ then for the trigger that is used at 20 gf. Hardness testing is done after the ice cream undergoes overnight storage. Ice cream hardness testing is carried out at 3 points, namely top, middle, and bottom. This hardness test was carried out 3 times for each sample [8].

\subsubsection{Total soluble solid}

Melting rate measurements are carried out by placing 50 grams of ice cream on a funnel for 30 minutes. Every 5 minutes the weight of the melted ice cream collected is weighed. The maximum time used is 30 minutes because it is adjusted to the general consumption time of ice cream. Whereas the time to melt is done by putting 50 grams of ice cream on the funnel for 180 minutes. Every 5 minutes, the weight of the melted ice cream collected is weighed. The maximum time used is 180 minutes [8].

\subsubsection{Total acid}

One gram of ice cream sample is first weighed and the sample is put into the Kjedahl flask. Then it was added to 7 grams of $\mathrm{K} 2 \mathrm{SO} 4$ ice cream, 0.35 grams of $\mathrm{HgO}$, and $15 \mathrm{ml}$ of concentrated $\mathrm{H} 2 \mathrm{SO} 4$. The flask is then degraded for 20 minutes at $420 \mathrm{oC}$ until the solution is clear and cooled until the temperature reaches $50-60 \mathrm{oC}$. After cooling the solution is distilled, then the resulting distillate is stored in an empty Erlenmeyer. To the distillation process, $50 \mathrm{ml}$ of $\mathrm{H} 2 \mathrm{O}, 25 \mathrm{ml}$ of $\mathrm{H} 3 \mathrm{PO} 3$ and $\mathrm{NaOH}$ of $10 \% 70 \mathrm{ml}$ was added. The distillation process is carried out for 3 minutes until a distillate is obtained. Then the distillate obtained was titrated using $0.1 \mathrm{~N} \mathrm{HCl}$ with a methylene red blue indicator of 3-4 drops. The distillate is titrated until it turns bluish [9].

\subsubsection{Fat}

The filter paper used is weighed, then the 1gram ice cream sample that has been extracted has a moisture content wrapped in filter paper and then weighed. Then the sample is put into a Soxhlet flask and the ether solvent is added up to $1 / 3$ part of the flask. Then extracted for 3-4 hours. The final step is the sample that has been obtained, dried in the oven for 3 hours. The sample is put in a desiccator for 15 minutes and weighed to contain fat content [9]

\subsubsection{Starch}

Enter 10 grams of sample into the Erlenmeyer then add $50 \mathrm{ml}$ of $8 \% \mathrm{KOH}$ alcohol solution then heat on a water bath for 20 minutes and stir. The sample then transferred to centrifugation tubes where the weight of each tube + solution must be balanced. The solution was then centrifuged for 5 minutes at $2000 \mathrm{rpm}$. The precipitate formed is washed with $25 \mathrm{ml}$ of $95 \%$ ethanol solution and stir well. After that, do centrifugation again for 5 minutes at $2000 \mathrm{rpm}$. The precipitate formed was added with $50 \mathrm{ml}$ of HCL and then stirred evenly. The precipitate formed, as much as $25 \mathrm{ml}$ was transferred into bekker glass and added with $75 \mathrm{ml}$ of $95 \%$ ethanol. The solution was mixed evenly and left for 1 night ( 24 hours), bekker glass was left in 
a closed condition. The solution is filtered with a filter paper of known weight. The filter paper was washed with $15 \mathrm{ml}$ of $95 \%$ ethanol solution and dried 30 minutes at $75 \mathrm{oC}$. After that, the filter paper was cooled in a desiccator for 15 minutes and weighed at a constant weight. Calculation of $\%$ starch formula [9].

$$
\% \text { starch }=\frac{100 \times(A-B) \times 2}{\text { sample }}
$$

Information: A : Filter paper + residue after dry

$$
\begin{aligned}
& \text { B : Dry filter paper } \\
& 2 \text { : correction factor }
\end{aligned}
$$

\section{Results and Discussions}

As some food rich in carbohydrates, green bean flour can act as a fat replacer. Green bean flour acts as a gelling agent due to its amylose and amylopectin content, so the flour can replace the role of fat to form the texture of ice cream. According to [10], starch is one of the glucose-type monosaccharide polymers which can be categorized into two fractions: the linear fraction form is amylose and the branched fraction is amylopectin. Starch is often used as a thickener, stabilizer, gelling agent, and water-binding agent.

The physical properties of the ice cream made of mung bean presented in Table 2 . The addition of mung bean flour has an influence on the physical quality of ice cream. In general, higher amount mung bean decreased the physical quality parameters such as hardness, viscosity, overrun, and melting rate of ice cream. The role of green beans as a fat replacer has a significant impact on the physical quality of ice cream.

Table 2. Physical Properties of Ice Cream Made from Various Ratios of Mung Bean Flour and Whipped Cream

\begin{tabular}{ccccc}
\hline Concentration & $\begin{array}{c}\text { Overrun } \\
(\mathbf{\%})\end{array}$ & $\begin{array}{c}\text { Viscosity } \\
(\mathbf{c P . S})\end{array}$ & Hardness (kgf) & $\begin{array}{c}\text { Melting rate } \\
(\mathbf{m i n})\end{array}$ \\
\hline A & $87.50 \pm 13.69^{\mathrm{b}}$ & $850 \pm 1.05^{\mathrm{a}}$ & $9.60 \pm 4.50^{\mathrm{a}}$ & $6.98 \pm 1.66^{\mathrm{b}}$ \\
$\mathrm{B}$ & $81.25 \pm 6.85^{\mathrm{ab}}$ & $646 \pm 0.10^{\mathrm{a}}$ & $12.31 \pm 3.51^{\mathrm{ab}}$ & $4.37 \pm 1.66^{\mathrm{a}}$ \\
C & $78.13 \pm 3.42^{\mathrm{ab}}$ & $1170 \pm 1.16^{\mathrm{a}}$ & $17.46 \pm 4.83^{\mathrm{bc}}$ & $4.15 \pm 1.37^{\mathrm{a}}$ \\
D & $71.88 \pm 3.42^{\mathrm{a}}$ & $2140 \pm 3.22^{\mathrm{b}}$ & $19.90 \pm 4.43^{\mathrm{c}}$ & - \\
\hline
\end{tabular}

Information :

1. Values are mean $\pm \mathrm{SD}$

2. A: Ice cream control with no addition mungbean flour; B: ice cream with addition $25 \%$ mung bean flour and $75 \%$ whipped cream; C: ice cream with addition $50 \%$ mung bean flour and $50 \%$ whipped cream; D: ice cream with addition $75 \%$ mung bean flour and $25 \%$ whipped cream. 
The addition of fat replacers in ice cream has been widely used, to make low-fat ice cream products. The role of fat replacer is to replace the role of fat as forming textures and in sensory factors for example creaminess, softness, and texture. Some types of fat replacer that are often used are inulin, maltodextrin, polydextrose, milk protein, soy protein, food fiber, and starch [11]. Mung beans are rich in carbohydrates and protein, and can be used as a texture forming ice cream replaces ice cream the role of whipped cream as a source of fat.

Table 2. shows that the addition of green bean flour will affect the overrun of the ice cream. Overrun are air cells that are inserted into the ice cream component during the freezing process so as to increase the volume of ice cream [11]. In this study, the higher mung bean flour addition reduced the overrun ice cream. Common ice cream overrun are in the ranged between $100-120 \%$ [2], while the value after mung bean substitution was only ranged between $87.50 \%$ to $71.88 \%$. However, according to SNI 01-3713-1995 the average level ice cream overrun is 70$80 \%$ for the industrial scale. Based on SNI, the use of green bean flour as a fat replacer in this study is still in the quality standard.

Overrun and fat content have a strong correlation and directly proportional. An increase in the concentration of mung bean flour will mainly reduce levels role fat of ice cream because whipped cream as a source of fat has been replaced by mung beans. Whipped cream is a product of fat component agitation that binds to one another, causing the formation of a rigid and dense texture. Churning triggers the formation of an initial stage and further shaking process causes the formation of air bubbles around the whipped cream, so that it will help to increase overrun ice cream [2]. The addition of mung bean flour in this study affect the value of overrun ice cream, decrease fat content increase the viscosity and hardness of ice cream.

Viscosity is one of the main components in the physical quality of ice cream. Viscosity influences how a sample of ice cream products reacts when consumed [12]. Several Relationship between fat substitution with fat replacer and viscosity of ice cream has been studied before. The higher amount of fat replacer increased the viscosity of ice cream [13]. The higher viscosity is due to the mung beans flour binds water to form a gel, so that it will give a thick nature to the ice cream. Table 1 shows the average viscosity of ice cream with the addition of green bean flour is 646-2140 cP.s. The result was supported by previous study which mentioned that the amount of various fat replacer gave no effect on ice cream viscosity [14].

Reducing fat content of ice cream and replacing with mung bean flour as a fat replacer increase the water binding capacity so that viscosity increases. Similar result has been report before [15], in which the use of modified starch to replace coconut milk as a source of fat lowering fat increased the viscosity of ice cream. The viscosity of ice cream shows different values. The difference between fat replacers will give different viscosity qualities [11]. 
Hardness is also one of the physical factors in ice cream, because the hardness has a correlation to the softness of the ice cream texture. Table 1 shows that higher amount of mung bean flour increased the hardness of ice cream. According to [16], reducing fat content will affect the ice cream texture. Fat replacer reduces the elastic properties which will then cause the texture to become harder. The decrease of fat cause the formation of ice crystals, thus causing the texture to be rough [17]. Hardness and fat content have a strong correlation. Lower whipped cream reduce levels of ice cream fat resulted in te harder texture. In addition, gelatinization properties of mung beens flour will bind water and form gel in ice cream, causing an increase in the hardness of ice cream [18].

Melting time increased along with the higher amount of mung bean flour (Table 1). Ice cream with $100 \%$ whipped cream gave the lowest melting time, so that reducing whipped cream as a source of fat, will affect the time to melt. According to (Sawitri, 2005), the standard melting rate of ice cream is 15-20 minutes when served at room temperature. In additon low-fat ice cream containing various concentrations of inulin has a weak tendency in melting rate when compared to control ice cream (without the addition of inulin) with 10\% fat content [19] [20]. Another sudy fund that a good ice cream is an ice cream that does not melt easily at room temperature [2]. The longer the melting rate indicates that the ice cream produced is more stable.

According to [21], melting time depends on the amount of air contained in the ice cream mixture. Mung bean flour as a component that is high in starch, affect the rate of ice cream melting. The gelatinizing nature of mung bean flour will bind the water component resulting in the increase of ice cream viscosity [15]. This causes mung bean flour to stabilize the melting time of ice cream.

Table 2. Chemical Properties of Ice Cream Made from Various Ratios of Mung Bean Flour and Whipped Cream

\begin{tabular}{ccccc}
\hline Concentration & $\begin{array}{c}\text { Moisture } \\
\mathbf{( \% )}\end{array}$ & $\begin{array}{c}\text { Protein } \\
(\mathbf{\%})\end{array}$ & $\begin{array}{c}\text { Fat } \\
(\mathbf{\%})\end{array}$ & $\begin{array}{c}\text { Starch } \\
\mathbf{( \% )}\end{array}$ \\
\hline A & $73.24 \pm 2.74^{\mathrm{a}}$ & $2.43 \pm 0.27^{\mathrm{a}}$ & $17.50 \pm 2.81^{\mathrm{a}}$ & $0.06 \pm 0.01^{\mathrm{a}}$ \\
B & $74.53 \pm 1.84^{\mathrm{a}}$ & $5.34 \pm 0.69^{\mathrm{b}}$ & $12.34 \pm 3.73^{\mathrm{b}}$ & $2.26 \pm 0.21^{\mathrm{b}}$ \\
C & $74.12 \pm 0.60^{\mathrm{a}}$ & $7.68 \pm 0.60^{\mathrm{c}}$ & $7.74 \pm 1.85^{\mathrm{c}}$ & $4.30 \pm 0.37^{\mathrm{c}}$ \\
D & $73.52 \pm 0.72^{\mathrm{a}}$ & $9.96 \pm 0.59^{\mathrm{d}}$ & $3.30 \pm 2.16^{\mathrm{d}}$ & $7.82 \pm 0.59^{\mathrm{d}}$ \\
\hline
\end{tabular}

Information:

1. Values are mean $\pm \mathrm{SD}$

2. A: Ice cream control with no addition mungbean flour; B: ice cream with addition $25 \%$ mung bean flour and 75\% whipped cream; C: ice cream with addition 50\% mung bean flour and 50\% whipped cream; D: ice cream with addition $75 \%$ mung bean flour and $25 \%$ whipped cream.

Table 2 show the substitution of green bean flour as a fat replacer in ice cream caused the decrease in the fat content of ice cream. The lower fat content in accordance with the purpose of this study, i.e. to reduce ice cream fat levels with substitution with mung bean flour. Moreover, 
the mung bean substitution increased starch and protein content. In other words, mung bean substitution affected the physical quality of resulted ice cream.

Fat is a major component of ice cream. Fat associated with improving the quality of ice cream, especially texture, mouthfeel, creaminess [22]. In addition, fats also contribute to the formation of flavors ice cream. Fat content relates to the physical characteristics of ice cream such as overrun, time to melt, hardness, and viscosity of the cream. The fat content of ice cream is 10$12 \%$ [16]. However according to (SNI 01-3713-1995), the standard ice cream fat is 5\% [23]. In this study, substitution of $25-50 \%$ of mung bean flour poduced ice cream with fat content ranging between $7.74-12.34 \%$. The use of $75 \%$ mung bean flour reduced fat content to $3.30 \%$, describing that the fat content can be lowered the ice cream quality standard.

Gelatinization properties of mung bean starches cause the increase in ice cream thickness. In which the affect the entry of air during the freezing and shaking process [18]. Other study reported that lso added by [16], the use of fat replacers that increase viscosity causes the bonding of molecules to be tighter. The tight molecule wil then prevent the air trapping during the shaking process, so that it will inhibit the development of the dough. [24] reported that, the use of maltodextrin as a fat replacer lessened fat content by a percentage of $6 \%$ to $8 \%$ and reduced the ice cream overrun. Another author [3] also reported that the fat substitution with $6 \%$ whey protein as a decrease in overrun ice cream.

The addition mung bean flour increased protein levels of the ice cream, which was ranging between 5.34 - 9.96\%. Meanwhile, according to (SNI 01-3713-1995, 1995), the standard level of ice cream protein is $2.7 \%$. This study found that the substitution of whipped cream with mung beans in making ice cream has an impact on reducing fat content, but it gavee an increase in protein ice cream.

\section{Conclusions}

Mung bean flour has the potential as a fat replacer to replace whipped cream as a source of fat in making ice cream. The potential use of mung bean flour as a fat replacer is at the concentration of $25-50 \%$ because it can provide the most optimal physical quality such as overrun, viscosity, and melting rate characteristics.

\section{REFERENCES}

[1] B. Nanan. N, S. Usmati, A, "Karakteristik Es Krim Labu Kuning (Curcubita moschata) Menggunakan Pengemulsi Pati Jagung (Zea Mays L.) Dan Pati Garut (Maranta arundinacea L.)," J. Pascapanen, vol. 7, no. 1, pp. 43-52, 2010.

[2] D. Goff, "Dairy Scienceand Technology Education Series," 1999. [Online]. Available: file:///C:/Users/USER/Downloads/Documents/3550983220.pdf. 
[3] T. Ö. Yilsay, L. Yilmaz, and A. A. Bayizit, "The effect of using a whey protein fat replacer on textural and sensory characteristics of low-fat vanilla ice cream," Eur. Food Res. Technol., vol. 222, no. 1-2, pp. 171-175, 2006.

[4] R. J. Baer, N. Krishnaswamy, and K. M. Kasperson, "Effect of Emulsifiers and Food Gum on Nonfat Ice Cream,” J. Dairy Sci., vol. 82, no. 7, pp. 1416-1424, 1999.

[5] R. Grossklaus and B. Germany, "I U bersichtsbeitrage / Reviews Fat Replacers Requirements from a Nutritional Physiological Point of View," no. December 1995, 2019.

[6] J. F. Borzelleca, "A proposed model for safety assessment of macronutrient substitutes," Regul. Toxicol. Pharmacol., vol. 23, no. 1 II, pp. 15-18, 1996.

[7] S. Umela. Analisis Mutu Es Krim kacang Hijau (Phaseolus radiatus L) Dan Susu Sapi Segar. Jtech J., vol. 4, no. 2, pp. 131-137, 2016.

[8] E. A. Prindiville, R. T. Marshall, and H. Heymann, "Effect of milk fat, cocoa butter, and whey protein fat replacers on the sensory properties of lowfat and nonfat chocolate ice cream," J. Dairy Sci., vol. 83, no. 10, pp. 2216-2223, 2000.

[9] AOAC, AOAC Official Methods of Analysis, vol. 15th, no. Volume 1. 1990.

[10] C. wai Chiu and D. Solarek, Modification of Starches, Third Edit. Elsevier Inc., 2009.

[11] M. Akbari, M. H. Eskandari, and Z. Davoudi, "Application and functions of fat replacers in low-fat ice cream: A review," Trends Food Sci. Technol., vol. 86, no. February, pp. 34-40, 2019.

[12] D. B. Aime, S. D. Arntfield, L. J. Malcolmson, and D. Ryland, "Textural analysis of fat reduced vanilla ice cream products," Food Res. Int., vol. 34, no. 2-3, pp. 237-246, 2001.

[13] J. S. Alakali, T. M. Okonkwo, and E. M. Iordye, "Effect of stabilizers on the physicochemical and sensory attributes of thermized yoghurt," African J. Biotechnol., vol. 7, no. 2, pp. 158-163, 2008.

[14] M. C. H. Lukman, H. Purwadi. \& Padaga, "Penambahan Gum Guar Pada Pembuatan Es Krim Instan Ditinjau Dari Viskositas, Overrun Dan Kecepatan Meleleh. 2015.

[15] S. Surapat and P. Rugthavon, "Use of Modified Starch as Fat Replacer in Reduced Fat Coconut Milk Ice Cream,” vol. 492, pp. 484-492, 2003.

[16] S. Adapa, H. Dingeldein, K. A. Schmidt, and T. J. Herald, "Rheological properties of ice cream mixes and frozen ice creams containing fat and fat replacers," J. Dairy Sci., vol. 83, no. 10, pp. 2224-2229, 2000.

[17] J. X. Guinard, C. Zoumas-Morse, L. Mori, B. Uatoni, D. Panyam, and A. Kilara, "Sugar and fat effects on sensory properties of ice cream," J. Food Sci., vol. 62, no. 5, pp. 10871094, 1997.

[18] A. Akesowan, "Influence of Soy Protein Isolate on Physical and Sensory Properties of Ice Cream," Thai J. Agric. Sci., vol. 42, no. 1, pp. 1-6, 2009.

[19] A. S. Akalin and D. Erişir, "Effects of inulin and oligofructose on the rheological characteristics and probiotic culture survival in low-fat probiotic ice cream," J. Food Sci., vol. 73, no. 4, 2008.

[20] B. Nagar, G.L; G, Clowes ; C, M, Tudorica ; \& C.S, "Rheological quality and stability of yog-ice cream with added inulin," Int. J. Dairy Technol., vol. 55, no. 89, pp. 89-94, 2002.

[21] M. M. R. Koxholt, B. Eisenmann, and J. Hinrichs, "Effect of the fat globule sizes on the meltdown of ice cream," J. Dairy Sci., vol. 84, no. 1, pp. 31-37, 2001.

[22] C. C. Akoh, "Fat-based fat substitutes," in Fatty Acids in Foods and their Health Implications, Third Edition, 2007, pp. 461-471.

[23] "SNI 01-3713-1995 Es Krim," 1995. 
[24] O. B. Karaca, M. Güven, K. Yasar, S. Kaya, and T. Kahyaoglu, "The functional, rheological and sensory characteristics of ice creams with various fat replacers," Int. J. Dairy Technol., vol. 62, no. 1, pp. 93-99, 2009. 